\title{
Repurposing of antiparasitic drugs: the hydroxy-naphthoquinone buparvaquone inhibits vertical transmission in the pregnant neosporosis mouse model
}

\author{
Joachim Müller ${ }^{1}$, Adriana Aguado-Martínez', Vera Manser ${ }^{1}$, Ho Ning Wong², Richard K. Haynes² \\ and Andrew Hemphill ${ }^{*}$
}

\begin{abstract}
The three anti-malarial drugs artemiside, artemisone, and mefloquine, and the naphthoquinone buparvaquone known to be active against theileriosis in cattle and Leishmania infections in rodents, were assessed for activity against Neospora caninum infection. All four compounds inhibited the proliferation of $\mathrm{N}$. caninum tachyzoites in vitro with $\mathrm{IC}_{50}$ in the sub-micromolar range, but artemisone and buparvaquone were most effective $\left(\mathrm{IC}_{50}=3\right.$ and $4.9 \mathrm{nM}$, respectively). However, in a neosporosis mouse model for cerebral infection comprising Balb/c mice experimentally infected with the virulent isolate Nc-Spain7, the three anti-malarial compounds failed to exhibit any activity, since treatment did not reduce the parasite burden in brains and lungs compared to untreated controls. Thus, these compounds were not further evaluated in pregnant mice. On the other hand, buparvaquone, shown earlier to be effective in reducing the parasite load in the lungs in an acute neosporosis disease model, was further assessed in the pregnant mouse model. Buparvaquone efficiently inhibited vertical transmission in Balb/c mice experimentally infected at day 7 of pregnancy, reduced clinical signs in the pups, but had no effect on cerebral infection in the dams. This demonstrates proof-of-concept that drug repurposing may lead to the discovery of an effective compound against neosporosis that can protect offspring from vertical transmission and disease.
\end{abstract}

\section{Introduction}

Neospora caninum is a cyst-forming apicomplexan parasite closely related to Toxoplasma gondii. $N$. caninum is one of the most important infectious causes of bovine abortion, stillbirth, and the birth of weak calves, with an economic impact of over 1.3 billion US dollars [1-3]. $N$. caninum infection can also result in birth of clinically healthy, but persistently infected calves transmitting the parasite to the next generation. In addition, $N$. caninum causes neuromuscular disease in dogs, and neosporosis has also been detected in a wide range of other species of livestock and wild animals worldwide.

\footnotetext{
${ }^{*}$ Correspondence: andrew.hemphill@vetsuisse.unibe.ch

1 Institute of Parasitology, Vetsuisse Faculty, University of Berne,

Länggass-Strasse 122, 3012 Bern, Switzerland

Full list of author information is available at the end of the article
}

Possible strategies to limit the economic impact of neosporosis include testing and culling of seropositive animals, discontinued breeding with offspring from seropositive cows, vaccination of susceptible and infected animals, and chemotherapeutical treatment of calves from seropositive cows $[4,5]$. However, the most effective option is not always the most economic one [6] and the suitability of any of these options has to be assessed $[6,7]$. As is the case for neglected diseases, one option for chemotherapy of neosporosis in cattle is the repurposing of drugs with well-documented antiparasitic activities [8-10]. The most prominent compounds in this context are certainly antimalarial drugs, for which enormous screening campaigns have been initiated, such as the high-throughput screening efforts of St. Jude Children's Research Hospital (TN, USA), Novartis and GlaxoSmithKline [11-13]. While such large screening campaigns 
cannot be carried out for $N$. caninum, simply due to the lack of resources, one possibility is to use a piggy-back approach and perform efficacy testing of selected drugs that are already either marketed or in clinical trials for human and/or veterinary use. By screening a larger panel of such compounds, we here report on the results obtained with the three antimalarials artemisone, artemiside, and mefloquine, and the naphthoquinone buparvaquone.

Artemisone and artemiside are artemisinin derivatives [14] that have shown promising efficacy against experimentally induced toxoplasmosis in mice [15]. Moreover, artemisone is highly active against $N$. caninum tachyzoites in vitro [16] and was shown to protect gerbils against cerebral infection [17]. Artemiside exhibits excellent efficacy against malaria in a murine model [18], but has not been tested against neosporosis so far. Mefloquine, one of the most common antimalarials [19], is active in a mouse model of Schistosoma mansoni infection [20] and shows promising results in Echinococcus multilocularis infected mice [21], but its effect against $N$. caninum has never been assessed. Buparvaquone was also originally developed as an anti-malarial compound [22] and is now commercially available (Butalex ${ }^{\circledR}$ ), for use in endemic regions against theileriosis in cattle. In other regions of the world, e.g., the EU, it is, however, not registered. In most cases only a single dose injection is required to cure Theileria-infected animals within a few days, with cure rates near to $100 \%$ when administered at the early stages of clinical disease [23]. The mode of action of buparvaquone has not been clarified, but there are indications that it blocks the parasite respiratory chain [22], and resistance against buparvaquone has been associated with mutations in the cytochrome b gene of the parasite [24, 25]. Besides exhibiting an outstanding activity against Theileria spp. [26, 27], buparvaquone is also active against other protozoan parasites including Leishmania spp. [28] and Babesia spp. [29]. Moreover, buparvaquone is highly active against $N$. caninum in vitro, and in a non-pregnant mouse model for acute disease we have recently shown that buparvaquone treatment protects mice against infection in the lungs, but not the brain, and prevents clinical signs of acute disease [30].

Here we applied a standardized Balb/c mouse model infected with the N. caninum NcSpain-7 isolate [31] to demonstrate that of these four compounds buparvaquone may have the potential to limit vertical transmission in $N$. caninum infected animals without inducing detrimental effects on pregnancy.

\section{Materials and methods}

\section{Tissue culture media, biochemicals, and drugs}

If not stated otherwise, all tissue culture media were purchased from Gibco-BRL (Zürich, Switzerland), and biochemical reagents were from Sigma (St. Louis, MO, USA). Kits for molecular biology were purchased from Qiagen (Hilden, Germany). Buparvaquone was provided by Cross Vetpharm Group Limited (Dublin, Ireland). Mefloquine was kindly supplied by Mepha Pharma AG (Aesch BL, Switzerland). Artemiside was synthesized according to the literature procedure [18] and artemisone was purified and supplied by Cipla Mumbai Ltd.

\section{Host cell cultivation and parasite cultures}

Tachyzoites of the N. caninum Nc-Spain7 isolate were cultured and prepared for infection as described [31].

\section{In vitro efficacy}

In vitro efficacies of the compounds were determined using a $N$. caninum beta-galactosidase reporter strain (Nc-beta-gal) and human foreskin fibroblasts (HFF) as host cells. Briefly, HFF were seeded into 96-well-plates, grown to confluence, and infected with $10^{3} \mathrm{Nc}$-beta-galtachyzoites per well in the presence of the compound to be tested or DMSO as a solvent control. After 3 days, medium was removed, and after one wash with PBS, cells were overlaid with $0.1 \mathrm{~mL}$ PBS containing Triton-X-100 $(0.05 \%)$ and chlorophenyl-red-beta-galactoside (Roche, Rotkreuz, Switzerland). Absorption was continuously read at $570 \mathrm{~nm}$ using a 96-well-plate spectrophotometer (Versamax, Molecular Devices, Sunnyvale CA) [16]. Host cell toxicity was determined by Alamar blue as described [30].

\section{Animal experimentation}

All protocols involving animals were approved by the Animal Welfare Committee of the Canton of Bern under the license BE115/14. All animals used in this study were handled in strict accordance with practices made to minimize suffering. Female and male BALB/c mice, 8 weeks of age, were purchased from a commercial breeder (Charles River, Sulzberg, Germany), and were maintained in a common room under controlled temperature and a $14 \mathrm{~h} / 10 \mathrm{~h}$ light cycle according to the guidelines set up by the animal welfare legislation of the Swiss Veterinary Office (approval No. BE 105/14).

\section{Assessment of the effects of mefloquine, artemisone, and artemiside on male BALB/c mice infected with $N$. caninum Spain-7}

Male Balb/c mice were randomly distributed in four groups of six mice each and subcutaneously infected with $10^{5}$ tachyzoites of the Nc-Spain7 isolate. At day 2 post infection (pi), one group received corn oil alone (placebo control), the others received mefloquine, artemiside, or artemisone $(50 \mathrm{mg} / \mathrm{kg} /$ day suspended in $100 \mu \mathrm{L}$ corn oil) for a period of 6 days by gavage once a day. At day $21 \mathrm{pi}$, 
the mice were euthanized. Blood was recovered by cardiac puncture and sera were obtained to assess humoral immune responses. Brains and lungs were removed for subsequent determination of parasite load and stored at $-20^{\circ} \mathrm{C}$ until further processing.

\section{Assessment of the effects of buparvaquone on non-pregnant and pregnant BALB/c mice infected with N. caninum Spain-7}

Fourty-eight female and 24 male BALB/c mice were housed, and pregnancy was achieved after synchronization of oestrus [31]. Subsequently, female mice were randomly distributed in 3 groups of 16 mice each. Mice from group 1 and 2 were subcutaneously infected with $10^{5}$ tachyzoites of the Nc-Spain7 isolate at mid gestation (days 7 after mating), while mice from group 3 were left uninfected and received a culture medium inoculation [31] At day $2 \mathrm{pi}$, all mice from group 1 received buparvaquone $(50 \mathrm{mg} / \mathrm{kg} /$ day suspended in $100 \mu \mathrm{L}$ corn oil) for a period of 6 days by gavage once a day, while the group 2 mice received corn oil alone. Prior to gavage, the corn oil-drug mixture was heated to $37^{\circ} \mathrm{C}$ to enhance solubility of the drug. Group 3 remained untouched. Pregnancy was confirmed between days 15-18 of gestation by weighing, and pregnant mice were then allocated into single cages to give birth on days 20-22 and to rear their pups for an additional 30 days. During this time, those females that had remained non-pregnant were maintained in cages of 3-5 mice. Non-pregnant mice were evaluated for clinical signs of disease twice daily and euthanized in a $\mathrm{CO}_{2}$ chamber latest at day 21 post infection. Concerning dams and pups, the litter size, i.e., the number of delivered pups per dam, early pup mortality defined as the number of full-term dead pups from birth until day 2 post partum (pp), post-natal mortality defined as the number of dead pups from day 3 to 30 p.p., and clinical signs were recorded. Surviving dams and pups were euthanized at 30 days p.p. (thus 44 days pi). Blood was recovered by cardiac puncture and sera were obtained to assess humoral immune responses. Brains were removed for subsequent determination of parasite load and stored at $-20{ }^{\circ} \mathrm{C}$ until further processing. The set-up of the in vivo experiments is shown in Table 1.

\section{Analysis of biological samples from in vivo experiments}

To quantify the parasite load in brains and lungs, DNA purification was performed employing the DNeasy Blood \& Tissue Kit (Qiagen, Basel, Switzerland) according to the standard protocol suitable for animal tissues. The DNA concentrations in all samples were determined using the QuantiFluor dsDNA System (Promega, Madison, Wi.,
Table 1 Overview of animal experiments presented in this study

\begin{tabular}{|c|c|c|}
\hline & Exp I & Exp II \\
\hline Gender & Males & Females \\
\hline Groups & 4, 6 mice per group & 3,16 mice per group \\
\hline Mating & No & Yes \\
\hline Challenge & Nc-Spain $7\left(10^{5}\right)$ & $\begin{array}{l}\text { Nc-Spain } 7\left(10^{5}\right), 7 \text { days post } \\
\text { mating }\end{array}$ \\
\hline Treatment & $\begin{array}{l}\text { ARI, ARO, MEF, placebo; } \\
\text { days 2-7 pi }\end{array}$ & BPQ, placebo; days 2-7 pi \\
\hline Euthanasia & 21 days pi & $\begin{array}{l}\text { non-pregnant: } 21 \text { days pi } \\
\text { dams: } 30 \text { days after birth, } \\
\text { i.e., } 44 \text { days pi }\end{array}$ \\
\hline Parameters & $\begin{array}{l}\text { N. caninum load in brains } \\
\text { and lungs, serum titer }\end{array}$ & $\begin{array}{l}\text { Number of pups, N. caninum } \\
\text { brain load, serum titer }\end{array}$ \\
\hline
\end{tabular}

$\mathrm{Balb} / \mathrm{c}$ mice were used throughout the experiment, either males for an in vivo pre-test of artemiside, artemisone or mefloquine (ARI, ARO, MEF; Exp I), or females for assessing the effectiveness of buparvaquone (BPQ) in a pregnant mouse model (Exp. II). pi, post infection with $10^{5}$ NcSpain7 tachyzoites.

USA) according to the manufacturer's instructions and adjusted with sterile DNAse free water to $5 \mathrm{ng} / \mu \mathrm{L}$. Quantification of parasite loads in brains and lungs was performed as described [30, 32]. Serum titers for $N$. caninum were assessed by ELISA as described [33, 34].

\section{Statistics}

Statistical analysis of the parasite burdens in brains was done using the Kruskal-Wallis test followed by Wilcoxon rank-sum-test. Survival analysis of the pups was performed on the corresponding Kaplan-Meier estimator using the log-rank-test. Nominal data were analyzed using the Chi square test. All analyses were performed using the software package $\mathrm{R}$ [35].

\section{Results}

In vitro efficacies of artemisone, artemiside, mefloquine and buparvaquone against $N$. caninum tachyzoites

Prior to in vivo studies, the efficacies of artemisone, artemiside, mefloquine, and buparvaquone against the proliferation of $N$. caninum tachyzoites in human foreskin fibroblasts were determined. Mefloquine and artemiside inhibited proliferation with a much higher $\mathrm{IC}_{50}$ than artemisone and buparvaquone as visualized by combining the inhibition curves of these four compounds at the same scale (Figure 1). In parallel, cytotoxicity of these four compounds on the human fibroblast host cells was assessed. Of these four compounds, only mefloquine showed a moderate host cell toxicity with an $\mathrm{IC}_{50}$ below $5 \mu \mathrm{M}$, while the other three compounds exhibited toxicity at concentrations only at concentrations above $5 \mu \mathrm{M}$ (Table 2). 


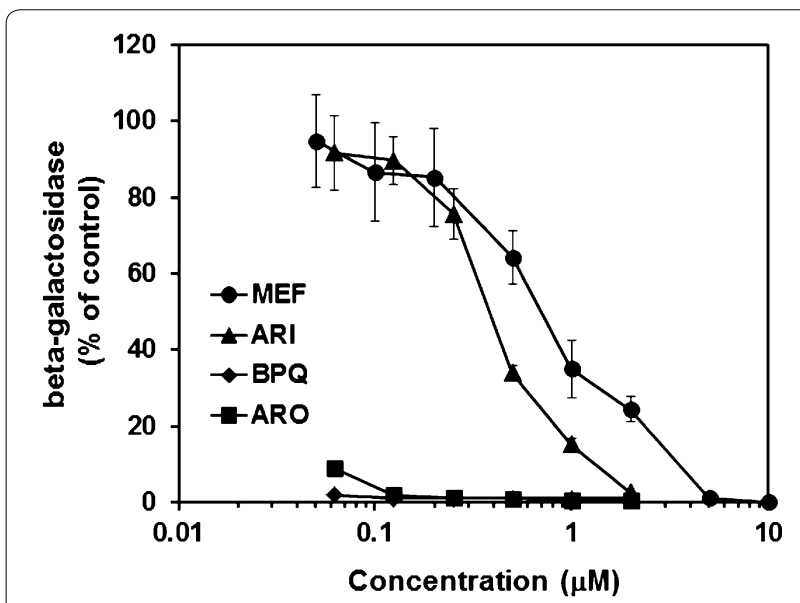

Figure 1 Inhibition of $\boldsymbol{N}$. caninum proliferation in vitro. Human foreskin fibroblasts (HFFs) were grown to confluence in 96-wellplates, treated with the compounds at various concentrations or with DMSO as a solvent control and infected with Nc-beta-gal tachyzoites ( $10^{3}$ per well). After 3 days, beta-galactosidase activity was determined. Mean values \pm SE are given for four wells relative to the solvent control.

In vivo efficacies in a Balb/c mouse model for cerebral $N$. caninum infection

In order to investigate whether artemisone, artemiside and mefloquine also affected $N$. caninum infection, the three anti-malarials were applied in male BALB/c that were infected with $10^{5} \mathrm{~N}$. caninum Nc-Spain7 tachyzoites. Two days pi, treatment with artemiside, artemisone, or mefloquine (50 mg/g bw in corn oil), or with corn oil alone was initiated and continued over 6 days. All mice were euthanized at day $21 \mathrm{pi}$. None of the mice showed clinical signs at this stage. The treatments had no effect on parasite loads either in the brain (Figure 2A) or in the lungs (Figure 2B). As a consequence, studies on female mice that had been mated to assess the effects on

Table 2 In vitro efficacies of the compounds used in this study

\begin{tabular}{lcll}
\hline Compound & $\mathbf{I C}_{\mathbf{5 0}} \mathbf{N c}$ & $\mathbf{I C}_{\mathbf{5 0}} \mathbf{H F F}$ & Reference \\
\hline Artemiside & $346(308-388)$ & $>5000$ & This work \\
Artemisone & $3(1-13)$ & $>5000$ & {$[16]$} \\
Buparvaquone & $4.9(4.0-5.9)$ & $>5000$ & {$[30]$} \\
Mefloquine & $941(775-1141)$ & $3643(3062-4335)$ & This work
\end{tabular}

Human foreskin fibroblasts (HFF) were grown to confluence in 96-well-plates, treated with the compounds at various concentrations or with DMSO as a solvent control, and after 3 days viability was measured using the Alamar blue assay. To determine the inhibition of $N$. caninum (Nc) tachyzoite proliferation (Nc), HFF monolayers were infected with Nc-beta-gal tachyzoites $\left(10^{3}\right.$ per well). After 3 days, beta-galactosidase activity was determined. $I C_{50}$ values (inhibitory concentration of $50 \%$ of the solvent control value) were calculated as described [16] and are given in $\mathrm{nM}$ (with 95\% confidence intervals).

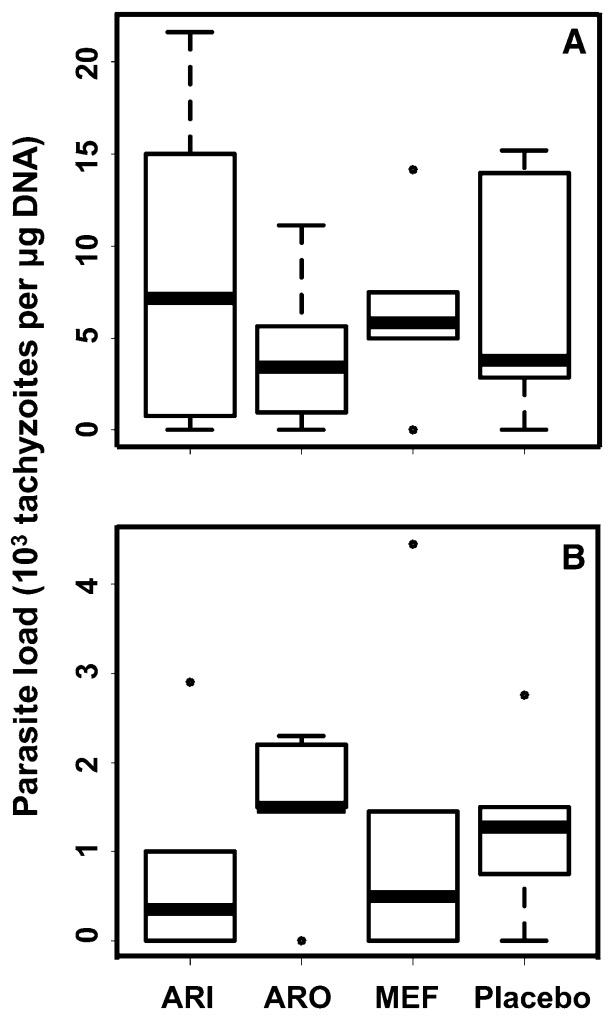

Figure 2 Parasite load in brains and lungs of mice treated with artemiside, artemisone, or mefloquine. Male BALB/C mice were infected with Nc-Spain7 tachyzoites and subsequently treated with artemiside (ARI), artemisone (ARO), mefloquine (MEF) in corn oil or corn oil only (Placebo) as detailed in Section "Materials and methods". The mice were euthanized 3 weeks pi. After euthanasia, brains and lungs were collected and the amount of tachyzoites was determined by quantitative PCR and are presented as box plots $(n=6)$. A brains, B lungs.

vertical transmission of $N$. caninum were performed only with buparvaquone.

Treatment of pregnant mice with buparvaquone protects pups from vertical transmission of $N$. caninum

The results on the effects of buparvaquone treatment in pregnant mice are summarized in Table 3 and Figure 5. Buparvaquone had no significant effects on the reproductive performance as assessed via determination of the pregnancy rate, the litter size and neonatal mortality (Table 3). After the dams had given birth, offspring and dams were maintained for 30 days in order to assess the long-term-impact during the post-natal phase in dams and offspring (Figure 5). Whereas five of eight dams of the placebo control group showed clinical signs and one died before the end of the experiment, none of the buparvaquone treated dams showed clinical signs and none of them died before the end of the experiment (Table 3). In all placebo treated dams and in six of 
Table 3 Effects of buparvaquone treatment on clinical signs, mortality, fertility and cerebral $N$. caninum NcSpain7 infection in non-pregnant mice, dams and pups

\begin{tabular}{llll}
\hline Parameter & BPQ & Placebo & No treatment \\
\hline Non-pregnant females & & & \\
Number & 8 & 8 & 7 \\
Clinical signs & $0 / 8$ & $0 / 8$ & $0 / 7$ \\
Mortality & $0 / 8$ & $0 / 8$ & $0 / 7$ \\
Seropositive & $8 / 8$ & $8 / 8$ & $0 / 7$ \\
Nc positive & $2 / 8^{*}$ & $8 / 8$ & $0 / 7$ \\
Dams and pups & & & \\
Number of dams & 8 & 8 & 8 \\
Clinical signs & $0 / 8^{+}$ & $5 / 8$ & $0 / 8$ \\
Mortality & $0 / 8^{* * *}$ & $1 / 8$ & $0 / 8$ \\
Seropositive dams & $8 / 8$ & $8 / 8$ & $0 / 8$ \\
Nc positive dams & $6 / 8^{* * *}$ & $8 / 8$ & $0 / 8$ \\
Pregnancy rate & $8 / 16$ & $8 / 16$ & $8 / 15$ \\
Total number of pups & 46 & 43 & 47 \\
Litter size average & $46 / 8^{* * *}$ & $43 / 8$ & $47 / 8$ \\
Neonatal mortality & \\
Postnatal mortality & $1 / 46^{* * *}$ & $2 / 43$ & $0 / 47$ \\
Nc positive pups & $18 / 45^{* *}$ & $40 / 41$ & $0 / 47$ \\
\hline BALB mine & $25 / 45^{* *}$ & $41 / 41$ & $0 / 47$
\end{tabular}

$B A L B / c$ mice were treated with buparvaquone $(B P Q)$ in corn oil or with corn oil alone (Placebo), infected with Nc-Spain7, or were neither treated nor infected (no treatment), and euthanized as described in Section "Materials and methods". Adults and surviving pups were tested for the presence of $N$. caninum in their brains by real time PCR. Pups that had died before the end of the experiment were considered as Nc positive. Respective numbers of animals in $\mathrm{BPQ}$ and placebo groups were compared by Chi square tests $\left({ }^{* * *} p>0.1,{ }^{+} p<0.1\right.$, ${ }^{*} p<0.05,{ }^{* *} p<0.001$ ).

a Proportion of pups born dead or that died within the two first days post partum.

b Proportion of pups dead from day 3 to $30 \mathrm{pp}$, considered as Nc positive.

eight buparvaquone treated dams $N$. caninum DNA was detected in the brain by real time PCR (Table 3 ).

None of the non-pregnant mice exhibited clinical signs of neosporosis during 3 weeks following infection (Table 3). In the buparvaquone treated group, the brain parasite load ranged between 0 and 450 tachyzoites per $\mu \mathrm{g}$ DNA as compared to 2700 and 31000 in the placebo control group. This difference was highly significant (Figure 3A). After 44 days pi, however, in dams that had given offspring, the cerebral parasite loads in buparvaquone-treated dams did not significantly differ from the parasite loads in the placebo groups (Figure 3B). All mice that had been infected were seropositive as assessed by ELISA (Table 3). In the non-pregnant females treated with buparvaquone, the serum titer was, however, not as high as in the placebo group (Figure 4A). In the infected dams, the serum titers were, however, at the same levels (Figure 4B).

For the offspring, two pups from the placebo group and one from the buparvaquone treated group died immediately after birth. During the next 28 days, 40 of the remaining 41 pups died in the control group, whereas only 18 of 45 in the buparvaquone-treated group died (Table 2). After 30 days, all survivors were tested by PCR for the presence of N. caninum in their brains. The last survivor from the placebo group was brain positive, as well as 7 out of 45 surviving pups from buparvaquone treated dams. Thus, mortality and transmission of $N$. caninum to pups were strongly reduced by buparvaquone treatment of the dams. The differences were highly significant (Table 2). This effect was even more apparent after analysis of the survival using the Kaplan-Meier-estimator as survival parameter and by comparing the resulting survival curves using the log-rank-test (Figures 4 and 5).

\section{Discussion}

In order to investigate whether drug repurposing may be a suitable strategy for obtaining suitable chemotherapeutic agents against neosporosis, we have tested four compounds, namely artemiside, artemisone, mefloquine, and buparvaquone, with proven efficacies against apicomplexan parasites in vitro and in mouse models. Three of these four compounds, artemiside, artemisone, and mefloquine did not affect the cerebral parasite load when assessed in a chronic infection model for $N$. caninum infection. This demonstrates that a low $\mathrm{IC}_{50}$ value against $N$. caninum tachyzoites obtained in vitro (in the case of artemisone; see also [16]) is not a predictive parameter for good in vivo effects. Moreover, our results are not in line with previous findings concerning effects of artemisone against neosporosis in gerbils [17]. However, in that study artemisone was administered by intraperitoneal injection as a formulation solubilized in DMSO, and the authors used another isolate (NcIS491) from Israel [36], which most likely differs in virulence from the Nc-Spain7 isolate used in this study. In a previous study on experimentally induced murine toxoplasmosis, DMSO solutions of artemisone and artemiside had been applied s.c. [15], but we refrained from this application mode due to potential side effects that is induced by this treatment based on own observations and on previously published results [37]. Oral application of mefloquine, shown to be effective against schistosomiasis [20] and more recently against Echinococcus infections in mice [38] did not exhibit any effects against $N$. caninum in this study.

Buparvaquone drastically limits the proliferation of $N$. caninum tachyzoites in vitro. In addition, we have previously shown that administration of buparvaquone protected mice that were infected with a high dosage $\left(2 \times 10^{6}\right)$ of $N$. caninum tachyzoites of the Nc-Liverpool isolate against acute neosporosis [30]. In the present study, by using a 20 times reduced infection dose $\left(10^{5}\right.$ tachyzoites), which does not lead to acute symptoms 


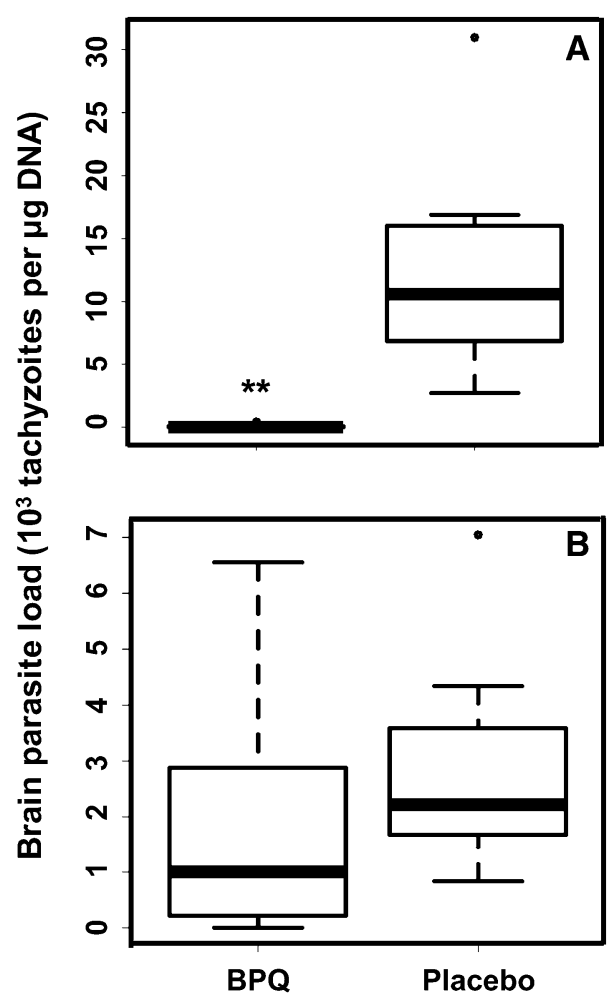

Figure 3 Cerebral parasite load in non-pregnant and pregnant mice treated with buparvaquone. $B A L B / C$ mice were infected with Nc-Spain7 tachyzoites and subsequently treated with buparvaquone (BPQ) in corn oil or corn oil only (Placebo) as detailed in Section "Materials and methods". Non-pregnant mice were euthanized 3 weeks pi, dams were euthanized 30 days post partum (pp), thus 44 days pi. After euthanasia, brains were collected and the amount of tachyzoites was determined by quantitative PCR and are presented as box plots (** $p<0.001$; Kruskal-Wallis-test). A non pregnant mice, B dams.

but to chronic infection followed by vertical transmission in dams [31], we demonstrate that in the short term, buparvaquone reduces the cerebral parasite load- as seen in the non-pregnant mice that were euthanized at 3 weeks pi. However, in the longer term, as seen in the dams that were euthanized 30 days after birth, that is, 44 days pi, no reduction in the cerebral parasite load was evident. This confirms earlier observations that buparvaquone is parasiticidal against $N$. caninum only after long term treatment [30]. Thus, 6 days of treatment is too short to eradicate the parasite from the dams, but the action of the drug during this short time span is sufficient to consistently impair vertical transmission to the offspring as evidenced by a significantly lower cerebral parasite load and a lower mortality in the offspring. Under the conditions in which we run our in vivo experiments (SPF animals, controlled access, qualified

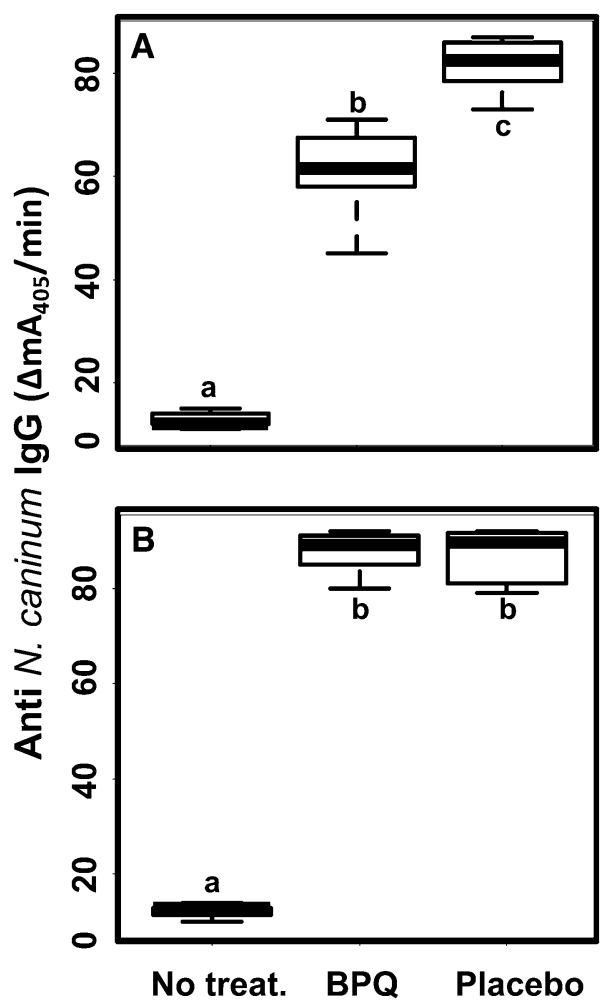

Figure 4 Anti total $\boldsymbol{N}$. caninum IgG serum levels. Balb/c mice were treated as described in Figure 3 (BPQ, Placebo) or left untreated. Serum samples were taken following euthanasia of non pregnant females $(\mathbf{A})$ or dams (B). ELISA wells were coated with Neospora caninum crude antigen. Values are presented as box-plots. Groups labelled with different letters are significantly different $(p<0.005$; Kruskal-Wallis-test followed by Wilcoxon rank sum test).

personnel), in uninfected, untreated animals, postnatal mortality does not occur. In the vertical transmission model [31], postnatal mortality occurs only upon dose dependent infection of the dams. Pups of infected dams die within 3 weeks; pups of not infected dams survive. The model is reproducible as shown in a more recent study [39].

In conclusion, this study shows that repurposing of established drugs facilitates the identification of compounds that may be applied for treatment of neosporosis, thus avoiding a long and costly drug development process. Other examples of potentially interesting compounds identified earlier through this avenue, and providing interesting results both in vitro and in vivo are miltefosine [40] and compounds belonging to the class of bumped kinase inhibitors (BKIs) that act against calcium-dependent protein kinase 1 , a target that is found in most apicomplexans [32, 39]. BKIs were originally developed to combat malaria [41]. Buparvaquone is already in use against Theileria infections in cattle in endemic 


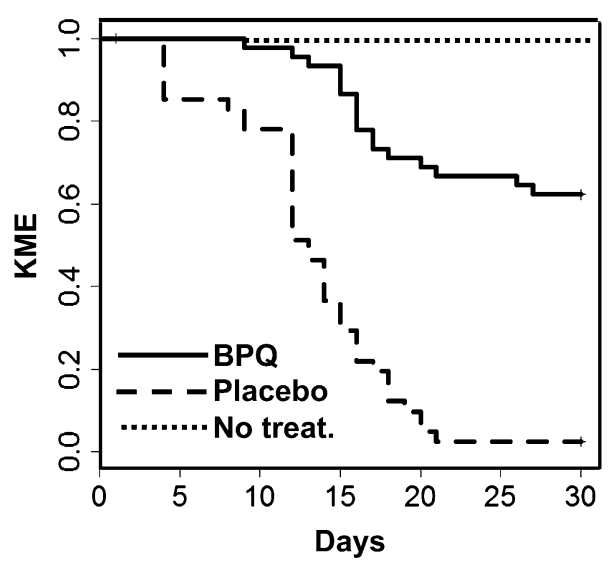

Figure 5 Offspring from buparvaquone treated dams had a higher survival rate as offspring from placebo treated dams. Survival curves of pups during 30 days pp of buparvaquone-treated (BPQ, solid line) and corn oil (Placebo, dashed line) treated dams, both of which were infected with Nc-Spain7 isolate of N. caninum. As a parameter for survival, the Kaplan-Meier-estimator (KME) is shown. The differences of BPQ and placebo survival curves were highly significant (log-rank-test; $p<10^{-12}$ ). In the untreated group (No treat.), no pup died (dotted line).

countries. Thus, it would be of interest to determine the incidence of neosporosis in buparvaquone treated cattle in those regions as compared to a control population that has not been treated. Moreover, studies in cattle will show whether buparvaquone treatments are able to eradicate $N$. caninum from the mother cows or whether they reduce the parasite to a low level chronic infection which may reactivate as soon as drug treatment is withdrawn. After establishment of a suitable treatment scheme, the effects on vertical transmission in cattle could be determined.

\section{Competing interests}

The authors declare that they have no competing interests.

\section{Authors' contributions}

RKH and NWH synthesized and provided the drugs used in this experiment. JM performed cell culture and in vitro studies. JM, AAM, AH and VM performed the animal experiments. JM, VM and AAM did the euthanasia, isolation of tissues and PCR assays, JM, AH, AAM and RKH wrote the paper. All authors read and approved the final manuscript.

\section{Acknowledgements}

We acknowledge the financial support by the Swiss National Science Foundation (Grant No. 310030 146162). RKH acknowledges funding from the South African Medical Research Council (MRC) with funds from National Treasury under its Economic Competitiveness and Support Package. Cipla Mumbai Pty Ltd. is thanked for the supply of purified artemisone, and we also thank Prof. Luis Ortega-Mora, Universidad Complutense Madrid, for providing the N caninum Spain-7 isolate.

\section{Author details}

${ }^{1}$ Institute of Parasitology, Vetsuisse Faculty, University of Berne, Länggass-Strasse 122, 3012 Bern, Switzerland. ${ }^{2}$ Centre of Excellence for Pharmaceutical Sciences, Faculty of Health Sciences G2, North-West University Potchefstroom Campus, 11 Hoffman Street, Potchefstroom 2531, South Africa.
Received: 11 December 2015 Accepted: 2 February 2016

Published online: 17 February 2016

\section{References}

1. Monney T, Hemphill A (2014) Vaccines against neosporosis: what can we learn from the past studies? Exp Parasitol 140:52-70

2. Reichel MP, Alejandra Ayanegui-Alcerreca M, Gondim LF, Ellis JT (2013) What is the global economic impact of Neospora caninum in cattle-the billion dollar question. Int J Parasitol 43:133-142

3. Dubey JP, Schares G, Ortega-Mora LM (2007) Epidemiology and control of neosporosis and Neospora caninum. Clin Microbiol Rev 20:323-367

4. Häsler B, Stark KD, Sager H, Gottstein B, Reist M (2006) Simulating the impact of four control strategies on the population dynamics of Neospora caninum infection in Swiss dairy cattle. Prev Vet Med 77:254-283

5. Häsler B, Regula G, Stark KD, Sager H, Gottstein B, Reist M (2006) Financial analysis of various strategies for the control of Neospora caninum in dairy cattle in Switzerland. Prev Vet Med 77:230-253

6. Reichel MP, Ellis JT (2006) If control of Neospora caninum infection is technically feasible does it make economic sense? Vet Parasitol 142:23-34

7. Reichel MP, Ellis JT (2009) Neospora caninum-how close are we to development of an efficacious vaccine that prevents abortion in cattle? Int J Parasitol 39:1173-1187

8. Sateriale A, Bessoff K, Sarkar IN, Huston CD (2014) Drug repurposing: mining protozoan proteomes for targets of known bioactive compounds. J Am Med Inform Assoc 21:238-244

9. Andrews KT, Fisher G, Skinner-Adams TS (2014) Drug repurposing and human parasitic protozoan diseases. Int J Parasitol Drugs Drug Resist 4:95-111

10. Matthews H, Usman-Idris M, Khan F, Read M, Nirmalan N (2013) Drug repositioning as a route to anti-malarial drug discovery: preliminary investigation of the in vitro anti-malarial efficacy of emetine dihydrochloride hydrate. Malar J 12:359

11. Gamo FJ, Sanz LM, Vidal J, de Cozar C, Alvarez E, Lavandera JL, Vanderwall DE, Green DV, Kumar V, Hasan S, Brown JR, Peishoff CE, Cardon LR, GarciaBustos JF (2010) Thousands of chemical starting points for antimalarial lead identification. Nature 465:305-310

12. Guiguemde WA, Shelat AA, Bouck D, Duffy S, Crowther GJ, Davis PH, Smithson DC, Connelly M, Clark J, Zhu F, Jimenez-Diaz MB, Martinez MS, Wilson EB, Tripathi AK, Gut J, Sharlow ER, Bathurst I, El Mazouni F, Fowble JW, Forquer I, McGinley PL, Castro S, Angulo-Barturen I, Ferrer S, Rosenthal PJ, Derisi JL, Sullivan DJ, Lazo JS, Roos DS, Riscoe MK, Phillips MA, Rathod PK, Van Voorhis WC, Avery VM, Guy RK (2010) Chemical genetics of Plasmodium falciparum. Nature 465:311-315

13. Meister S, Plouffe DM, Kuhen KL, Bonamy GM, Wu T, Barnes SW, Bopp SE, Borboa R, Bright AT, Che J, Cohen S, Dharia NV, Gagaring K, Gettayacamin M, Gordon P, GroessI T, Kato N, Lee MC, McNamara CW, Fidock DA, Nagle A, Nam TG, Richmond W, Roland J, Rottmann M, Zhou B, Froissard P, Glynne RJ, Mazier D, Sattabongkot J, Schultz PG, Tuntland T, Walker JR, Zhou Y, Chatterjee A, Diagana TT, Winzeler EA (2011) Imaging of Plasmodium liver stages to drive next-generation antimalarial drug discovery. Science 334:1372-1377

14. Ansari MT, Saify ZS, Sultana N, Ahmad I, Saeed-Ul-Hassan S, Tariq I, Khanum M (2013) Malaria and artemisinin derivatives: an updated review. Mini Rev Med Chem 13:1879-1902

15. Dunay IR, Chan WC, Haynes RK, Sibley LD (2009) Artemisone and artemiside control acute and reactivated toxoplasmosis in a murine model. Antimicrob Agents Chemother 53:4450-4456

16. Müller J, Balmer V, Winzer P, Rahman M, Manser V, Haynes RK, Hemphill A (2015) In vitro effects of new artemisinin derivatives in Neospora caninum-infected human fibroblasts. Int J Antimicrob Agents 46:88-93

17. Mazuz ML, Haynes R, Shkap V, Fish L, Wollkomirsky R, Leibovich B, Molad T, Savitsky I, Golenser J (2012) Neospora caninum: in vivo and in vitro treatment with artemisone. Vet Parasitol 187:99-104

18. Guo J, Guiguemde AW, Bentura-Marciano A, Clark J, Haynes RK, Chan WC, Wong HN, Hunt NH, Guy RK, Golenser J (2012) Synthesis of artemiside and its effects in combination with conventional drugs against severe murine malaria. Antimicrob Agents Chemother 56:163-173

19. Hall AP (1976) The treatment of malaria. Br Med J 1:323-328 
20. Keiser J, Chollet J, Xiao SH, Mei JY, Jiao PY, Utzinger J, Tanner M (2009) Mefloquine-an aminoalcohol with promising antischistosomal properties in mice. PLoS Negl Trop Dis 3:e350

21. Küster T, Stadelmann B, Hermann C, Scholl S, Keiser J, Hemphill A (2011) In vitro and in vivo efficacies of mefloquine-based treatment against alveolar echinococcosis. Antimicrob Agents Chemother 55:713-721

22. Hudson AT, Randall AW, Fry M, Ginger CD, Hill B, Latter VS, McHardy N, Williams RB (1985) Novel anti-malarial hydroxynaphthoquinones with potent broad spectrum anti-protozoal activity. Parasitology 90:45-55

23. McHardy N, Wekesa LS, Hudson AT, Randall AW (1985) Antitheilerial activity of BW720C (buparvaquone): a comparison with parvaquone. Res Vet Sci 39:29-33

24. Sharifiyazdi H, Namazi F, Oryan A, Shahriari R, Razavi M (2012) Point mutations in the Theileria annulata cytochrome $b$ gene is associated with buparvaquone treatment failure. Vet Parasitol 187:431-435

25. Mhadhbi M, Chaouch M, Ajroud K, Darghouth MA, BenAbderrazak S (2015) Sequence polymorphism of cytochrome b gene in Theileria annulata Tunisian isolates and its association with buparvaquone treatment failure. PLoS One 10:e0129678

26. Hostettler I, Müller J, Stephens CE, Haynes R, Hemphill A (2014) A quantitative reverse-transcriptase PCR assay for the assessment of drug activities against intracellular Theileria annulata schizonts. Int J Parasitol Drugs Drug Resist 4:201-209

27. Hashemi-Fesharki R (1991) Chemotherapeutic value of parvaquone and buparvaquone against Theileria annulata infection of cattle. Res Vet Sci 50:204-207

28. Croft SL, Hogg J, Gutteridge WE, Hudson AT, Randall AW (1992) The activity of hydroxynaphthoquinones against Leishmania donovani. J Antimicrob Chemother 30:827-832

29. Zaugg JL, Lane VM (1992) Efficacy of buparvaquone as a therapeutic and clearing agent of Babesia equi of European origin in horses. Am J Vet Res 53:1396-1399

30. Müller J, Aguado-Martinez A, Manser $\vee$, Balmer V, Winzer P, Ritler D, Hostettler I, Solís D, Ortega-Mora LM, Hemphill A (2015) Buparvaquone is active against Neospora caninum in vitro and in experimentally infected mice. Int J Parasitol Drugs Drug Resist 5:16-25

31. Arranz-Solis D, Aguado-Martinez A, Müller J, Regidor-Cerrillo J, OrtegaMora LM, Hemphill A (2015) Dose-dependent effects of experimental infection with the virulent Neospora caninum Nc-Spain7 isolate in a pregnant mouse model. Vet Parasitol 211:133-140
32. Ojo KK, Reid MC, Kallur Siddaramaiah L, Müller J, Winzer P, Zhang Z, Keyloun KR, Vidadala RS, Merritt EA, Hol WG, Maly DJ, Fan E, Van Voorhis WC, Hemphill A (2014) Neospora caninum calcium-dependent protein kinase 1 is an effective drug target for neosporosis therapy. PLoS One 9:e92929

33. Debache K, Alaeddine F, Guionaud C, Monney T, Müller J, Strohbusch M, Leib SL, Grandgirard D, Hemphill A (2009) Vaccination with recombinant $\mathrm{NCROP} 2$ combined with recombinant NcMIC1 and NCMIC3 reduces cerebral infection and vertical transmission in mice experimentally infected with Neospora caninum tachyzoites. Int J Parasitol 39:1373-1384

34. Debache K, Guionaud C, Alaeddine F, Mevissen M, Hemphill A (2008) Vaccination of mice with recombinant NCROP2 antigen reduces mortality and cerebral infection in mice infected with Neospora caninum tachyzoites. Int J Parasitol 38:1455-1463

35. R Core Team (2012) R: A language and environment for statistical computing

36. Fish L, Mazuz M, Molad T, Savitsky I, Shkap V (2007) Isolation of Neospora caninum from dairy zero grazing cattle in Israel. Vet Parasitol 149:167-171

37. Colucci M, Maione F, Bonito MC, Piscopo A, Di Giannuario A, Pieretti S (2008) New insights of dimethyl sulphoxide effects (DMSO) on experimental in vivo models of nociception and inflammation. Pharmacol Res 57:419-425

38. Küster T, Stadelmann B, Rufener R, Risch C, Müller J, Hemphill A (2015) Oral treatments of Echinococcus multilocularis-infected mice with the anti-malarial drug mefloquine that potentially interacts with parasite ferritin and cystatin. Int J Antimicrob Agents 46:546-551

39. Winzer P, Müller J, Aguado-Martínez A, Rahman M, Balmer V, OrtegaMora L, Ojo KK, Fan E, Maly D, Van Voorhis WC, Hemphill A (2015) In vitro and in vivo effects of the bumped kinase inhibitor 1294 in the related cyst-forming apicomplexans Toxoplasma gondii and Neospora caninum. Antimicrob Agents Chemother 59:6361-6374

40. Debache K, Hemphill A (2012) Effects of miltefosine treatment in fibroblast cell cultures and in mice experimentally infected with Neospora caninum tachyzoites. Parasitology 139:934-944

41. Ojo KK, Pfander C, Mueller NR, Burstroem C, Larson ET, Bryan CM, Fox AM, Reid MC, Johnson SM, Murphy RC, Kennedy M, Mann H, Leibly DJ, Hewitt SN, Verlinde CL, Kappe S, Merritt EA, Maly DJ, Billker O, Van Voorhis WC (2012) Transmission of malaria to mosquitoes blocked by bumped kinase inhibitors. J Clin Invest 122:2301-2305

\section{Submit your next manuscript to BioMed Central and we will help you at every step:}

- We accept pre-submission inquiries

- Our selector tool helps you to find the most relevant journal

- We provide round the clock customer support

- Convenient online submission

- Thorough peer review

- Inclusion in PubMed and all major indexing services

- Maximum visibility for your research

Submit your manuscript at www.biomedcentral.com/submit

\section{() Biomed Central}

